\title{
Teodor Oancă, Cercetări de onomastică și dialectologie, Editura Grafix, Craiova, 2019, 185 p.
}

\author{
Ana-Maria Prisacaru ${ }^{\mathbb{R}^{\mathrm{R}} \star}$ \\ Institutul de Filologie Română „A. Philippide”, Str. Th. Codrescu 2, 700481 Iași, România
}

Pornind de la ideea că „numele de familie pot fi considerate documente de natură lingvistică” (p. 6), cercetătorul Teodor Oancă adună în volumul de față 15 studii și articole axate, în principiu, pe cercetare onomastică şi dialectologică, surprinsă însă în context interdisciplinar prin raportare la etnografie, semantică, sociolingvistică și formarea cuvintelor. Această manieră de cercetare, inițiată în anii 19741975 în vederea elaborării tezei de doctorat Toponimia din Cîmpia Băileştiului-după cum mărturisește autorul în Argument - , capătă substanţă în anii următori prin redactarea și publicarea unor lucrări de referință pentru publicul interesat de onomastică: Probleme controversate în cercetarea onomastică românească (1996), Geografie antroponimică românească. Metodă și aplicații (1998), Onomastică și dialectologie (1999), Microsisteme antroponimice românești (2016), Contribuţii onomastice (2018), Dicționar de frecvență a numelor de familie din România (redactor, 2003), Dicționarul toponimic al României. Oltenia (colaborator) ș.a.

Articolul care deschide seria contribuțiilor științifice inserate în acest volum este dedicat geografiei antroponimice: Contribuții la delimitarea ariilor dialectale cu ajutorul geografiei antroponimice (p. 1223). Această metodă de cercetare, prin care un antroponim, în special nume de familie, este analizat prin prisma frecvenței lui în diferite unități administrative (județe), are menirea de a aduce „,reconsiderări asupra unor arii dialectale" (p. 12) prin înregistrarea unui nume de familie provenit dintr-un termen dialectal într-un areal mult mai amplu decît cel al bazei apela- tivice. Pentru a da doar un exemplu, vom menționa aici maniera de reconstituire a ariei dialectale de vest a termenului agud. Deși acesta este specific Moldovei, estului Munteniei și județului Tulcea, totuși în Moldova sînt consemnate doar patru nume de familie provenite de la acest apelativ. În Crişana, însă, unde termenul în uz este sinonimul frăgar, antroponimul Agud este înregistrat de 184 de ori. Explicaţia oferită de autor constă în faptul că în secolul al XVIIIlea, cînd s-au instituţionalizat numele de familie în Transilvania, Maramureș, Crișana și Banat, cuvintul agud era încă activ în graiurile din vestul țării. Ulterior, acesta a fost înlăturat de termenii concurenți frăgar și pomniţar, însă s-a menținut ca nume de familie.

$\mathrm{Al}$ doilea articol, Antroponime cu consoana labială inițială $[p]$ palatalizată (p. 24-32), are ca punct de plecare o paralelă, prezentată într-o Anexă, între nume de familie (extrase din $\mathrm{BDAR}^{1}$ ) la care se manifestă palatalizarea labialei [p] (Chele, Cheptănaru, Chetraru, Chitaru, Chistol etc.) și aceleași antroponime cu consoana iniţială $[\mathrm{p}]$ nealterată. Încă o dată, geografia antroponimică ị̂i dovedește eficiența în confirmarea distribuției acestui fenomen fonetic și în zona sudică a Olteniei ${ }^{2}$ - sub rezerva deplasării în teritoriu a indivizilor, care a condus la înregistrarea unor nume de familie cu această particularitate fonetică și în zone nespecifice.

Gruparea „sub aspect semantic a termenilor de origine a numelor de familie" (p. 33), cu alte cuvinte identificarea microsistemelor antroponimice este o preocupare constantă a autorului ${ }^{3}$, regăsită și în stu-

*Adresă de corespondență: carpanamaria@yahoo.co.uk.

${ }^{1}$ Baza de date antroponimice a României, creată în 1994 de cercetătorii din cadrul Laboratorului de Cercetări Onomastice de la Facultatea de Litere a Universității din Craiova prin prelucrarea informațiilor puse la dispoziție, pe suport electronic, de Inspectoratele județene de poliție și Serviciul de Evidență a Populației (p. 11).

${ }^{2}$ Această concluzie este confirmată și de cercetarea toponimică întreprinsă de autor în zona Cîmpiei Băileștiului, unde sînt înregistrate nume de locuri provenite de la apelative care prezintă diferite stadii de palatalizare (vezi Teodor Oancă, Onomastică și dialectologie, 1999).

${ }^{3}$ Vezi, în acest sens, Microsisteme antroponimice românești (2016) și Contribuții onomastice (2018). 
diul Particularități fizice, psibice, morale și de comportament generatoare de antroponime (p. 33-60). Sînt discutate aici nume de persoană provenite de la porecle, expresive și nonexpresive, care desemnează particularitățile anunțate în titlu. Pornind de la expresia „a pune suflet”, Teodor Oancă consideră că antroponimul Suflet „numește o persoană care dovedește multă pricepere în ceea ce face” (p. 38). Pe de altă parte, expresia „a trăi pe călcîi (picior) mare” îl inspiră pe cercetător, în mod hazardat am spune, să considere sinonime poreclele Boer, Călcîi șii Picior. Deoarece sursa antroponimelor (și a poreclelor care au stat la baza lor) analizate în acest studiu o constituie BDAR, care a fost realizată din informații obținute de la Serviciul de Evidență a Populației, credem că unele explicații avansate de autor trebuie puse sub semnul probabilității pînă la verificarea lor prin anchete de teren (deși, în cazul poreclelor care au devenit supranume și apoi nume de familie, motivele alegerii lor pentru a desemna o anumită persoană nu mai pot fi identificate). De exemplu, Teodor Oancă afirmă că poreclirea prin culori ar indica ,vîrsta (Albu, Bălan), sau o stare emoțională (Albastru, Galben, Negru, Roșu)" (p. 37); dar, credem noi, cuiva i s-ar putea spune $A l b u(l)$ și din cauza unui ten mai deschis, nu doar pentru că are părul cărunt, iar bălan trimite mai degrabă spre o persoană cu păr blond (dacă nu cumva porecla a fost ținta ironiei și persoana denumită era chiar brunetă!). Relativ obscură rămîne pentru noi și relaționarea culorilor albastru și galben cu anumite emoții. În cazul culorilor negru și roșu, deși admitem că pot trimite la stări precum supărare, respectiv furie, considerăm că autorul trebuia să aibă în vedere și contextul în care Negru ar putea desemna o persoană cu pielea mai închisă și Roşu, o persoană roșcată sau care se înroșește excesiv la față în anumite circumstanțe.

Pentru a rămîne în același registru, menționăm și articolul De la nume de unelte la nume de familie (p. 166-172), în care se discută posibilitatea constituirii într-un microsistem a numelor de familie provenite din porecle care au la bază nume de unelte, cu precizarea că frecvența și distribuția lor teritorială depinde de gradul de specializare a uneltei (Baros 412 înregistrări în BDAR vs. Ciocan - 16991 înregistrări) și de apartenența etimonului la un anumit grai românesc (Ilău, de exemplu, este foarte frecvent în Moldova, în timp ce numele de familie provenit de la termenul sinonim nicovală nu apare în $\mathrm{BDAR}$ ).

Articolul Toponime compuse cu determinant adjectival în Cîmpia Băileştiului (p. 61-69) aduce în atenția cititorilor nume de locuri înregistrate în anchetele toponimice premergătoare realizării Dicționarului Toponimic al României. Oltenia. Analiza sintagmelor toponimice din zona avută în vedere relevă ca model formativ dominant pe cel constituit din substantiv (entopic) + determinant adjectival, acesta din urmă desemnînd geografia „domoală” a regiunii ${ }^{4}$ și marcînd adesea relații de diferențiere toponimică (Balta Mare vs. Balta Mică, Biserica Nouă vs. Biserica Veche, Covei $\rightarrow$ Coveiu Mare vs. Coveiu Mic, Desnățui $\rightarrow$ Desnățiul Mic).

Un articol consistent este cel care tratează relația entopic-toponim în Cîmpia Băileștiului (p. 70-84). După prezentarea principalelor opinii de specialitate asupra categoriei restrînse a entopicelor, delimitată de categoria mai amplă a apelativelor, autorul se oprește asupra unor toponime din zona vizată, extrapolînd analiza asupra întregii Oltenii pentru a arăta că unii termeni geografici „îs,i specializează sensul” în zone mai restrînse (p. 73), căpătînd uneori o semnificație contrară sensului general. De exemplu, entopicul forestier tufă, cu sensul de „pădure mică, tufiș” în sudul Olteniei, intră în opoziția logică mare - mic/tînăr cu entopicul pădure: La Tufă „pădurice”, La Tufan "pădurice” (p. 74). În aceeași zonă, însă, tufă înseamnă și „stejar”. Tufărel, de pildă, desemnează o "fostă pădure mică de stejar” și Tufanu lu Mateescu indică un „stejar în vii” (p. 75). Transferul de sens de la un termen geografic la altul este un alt fenomen întîlnit în arii restrînse: entopicul ostrov, de exemplu, cu sensul primar de „insulă” (Ostrovu lu Mirica „insulă în Dunăre”, Ostrovu Mare „insulă în Dunăre"), preia, în sudul Olteniei, și sensul entopicului luncă, denumind la Cetate „o fîșie de pămînt, împădurită, de-a lungul Dunării” (p. 84).

Două dintre articole pun în discuție originea şi semnificația, pe teritoriul Olteniei, a apelativelor hotar (Sensul apelativului hotar în sudul Olteniei) și arămuc (Arămuc, rămuc - atestareși origine). Pentru primul lexem se stabilește sensul de „limită, margine, sfîrșit” în sudul Olteniei, fără a cumula, ca în partea de nord a acestei regiuni, și semnificația de „tot pămîntul care ține de un sat", pentru care se folosește

${ }^{4}$ „Un adjectiv ca repede, des întîlnit în toponimia zonelor de munte sau de deal, nu caracterizează niciun hidronim din toponimia actuală a Cîmpiei Băileștiului” (p. 62). 
temenul moşie. Apelativul arămuc este înregistrat pentru prima oară de Emil Petrovici, la Zimnicea, ca răspuns la întrebarea „Cum îi ziceți unei grămezi de oi care este mai mică decît o turmă ?". Termenul apare consemnat ulterior în sud-estul Olteniei sub forma rămúc, -múĉe, avînd sensul de „10-25 de oi strînse la un loc”. În privința originii, autorul îl pune în legătură cu tc. ramak „cantitate mică” (care nu depășește 40 de unități $)^{5}$. Discutabilă rămîne proteza lui $a-$, pe care autorul fie o pune pe seama contactului românilor din dreapta Dunării cu aromânii, fie o explică prin analogie cu perechi de termeni care au circulat cu și fără a protetic (alămîie - lămîie, alăută - lăută etc.).

Numele personal din perspectivă sociolingvistică (p. 90-116) este un studiu bogat documentat al schimbărilor de nume survenite în perioada 19811985, solicitate fie de părinţii purtătorului numelui, fie chiar de purtătorul ajuns la vîrstă adultă. Pe lîngă modificarea stării civile a petiționarului sau încercarea de corectare a numelor înscrise greșit în registrele de stare civilă din neglijența ori a părinților, ori a funcționarilor, motivele schimbării numelor „reflectă, în bună parte, factorii socioculturali care influențează individul, familia și mediul căruia îi aparține petiționarul” (p. 93): renunțarea la diminutive și hipocoristice, înlocuirea numelor demodate sau inestetice, predilecția pentru nume considerate „orășenești”, preluarea unor nume străine „la modă” etc.

Patru dintre studiile cuprinse în acest volum sînt consacrate analizei unor sufixe antroponimice. Primul dintre acestea, Antroponime cu dublu sufix de apartenență (p. 117-121), aduce în discuţie numele de familie la care sufixul patronimic românesc - escu se atașează unei baze antroponimice terminate în $-o v /-e v$, sufix cu aceeași valoare de apartenență familială (Birovescu, Iancovescu etc.). Dubla derivare a fost posibilă, explică autorul, deoarece sufixul slav, impus de redactorii actelor slavo-române în defavoarea românescului -escu ${ }^{6}$, și-a pierdut semnificația pentru români, astfel încît antroponimele derivate cu $-o v /-e v$ ajung să fie considerate „nume simple terminate în consoană” (p. 118). În privința originii antroponimelor de acest tip, posibilitatea provenienței unora dintre ele din slavă (Birovescu < bg. Birov, Iscovescu < bg. Iscovici ș.a.) este infirmată, după cum arată autorul, de existența în română a bazelor antroponimice: Bira/Biru - care apare și în nume precum Biraescu/Birăescu, Birău etc., Iscu - nume atestat încă din secolul al XVII-lea (p. 118-120). Credem că prezența aceleiași baze antroponimice nu doar în bulgară, ci şi în română nu este un argument pentru negarea originii bulgare a acestor derivate antroponimice cu sufixul -ov (care nu este românesc, ci slav). Ulterior, acestor derivate antroponimice bulgare le-a fost atașat, pe terenul limbii române, sufixul -escu.

Următorul studiu din seria dedicată derivării numelor de familie românești este o amplă discuție despre sufixul antroponimic -cea (p. 122-128). Cu valoare diminutivală, acest sufix ne este prezentat ca fiind compus din $-c i u+-e a^{7}$, find implicat în generarea unor „nume bărbătești, diminutive ale numelor sau supranumelor de la care s-au format" (p. 124). Pentru o perspectivă exactă asupra frecvenței acestui sufix în onomastica românească, autorul atrage atenția asupra necesităţii distingerii între numele proprii formate cu -cea (Balancea < Bălan, Bătrîncea < Bătrînu, Țigancea < Țiganu) și numele rezultate prin derivarea bazelor antroponimice românești sau slave, terminate în $c(+$ vocală $)$, respectiv în $c / c$, cu sufixul - ea sau -a (Butucea < Butuc, Colacea < Colac etc.). Pentru acuratețea analizei credem că se impune și distincția clară între derivatele antroponimice românești discutate de autor în acest studiu și derivatele antroponimice slave care circulă la noi, în acest ultim caz sufixul -cea comportînd alte explicații privind structura și originea, cea mai vehiculată ipoteză fiind proveniența din sl. $-\check{c} e$ cu valoare diminutivală ${ }^{8}$.

Al doilea sufix antroponimic românesc analizat este -ilă (p. 129-151), cu valoare augmentativă, dar și cu valoare expresivă atunci cînd exprimă o exagerare a particularităților persoanelor denumite. În privința provenienței acestui sufix, autorul notează că „cele mai multe opțiuni sînt pentru origine

\footnotetext{
${ }^{5}$ „[...] o cantitate care depășește numărul 40 este echivalentă [în limba turcă] cu kîrk, în sensul de «mult»” (p. 88).

${ }^{6}$ In contextul slavizării deliberate a numelor românești de către diecii străini, considerăm improprie calificarea acestor antroponime drept „creații românești” (p. 121).

${ }^{7}$ Informația este preluată de autor din N.A. Constantinescu, Dicționar Onomastic Românesc, 1963, p. LVII.

${ }^{8}$ Vezi Iorgu Iordan, Toponimia românească, 1963, p. 535. Pentru alte discuții privind etimologia acestui sufix, vezi Mic dicţionar toponimic al Moldovei (structural și etimologic). Partea 1. Toponime personale, 2014, s.v. Vrancea.
} 
slavă” (p. 133). Deși numeroase, nu toate creaţiile antroponimice cu acest sufix s-au impus ca nume de familie, în BDAR fiind înregistrate doar 140 de astfel de derivate de la un „supranume cu valoare de nume de familie neoficial în secolul al XIX-lea" (p. 132): Băcilă (< Baciu), Berbecilă (< Berbec), Manoilă (< Manole) etc.

Un articol amplu documentat este și cel despre sufixele antroponimice perechi -aca/-aga, -eca/-ega, -ical-iga, -oca/-oga, -uca/-uga (p. 152165), cercetate atît din perspectiva originii și a posibilităţii încadrării lor într-un sistem, cît şi prin raportare la sufixele corespunzătoare de la nivelul limbii comune. Se discută, de asemenea, și valoarea finalei $-a$ din structura acestor sufixe antroponimice, infirmîndu-se funcția ei moțională, deoarece numele de persoană derivate cu aceste sufixe sînt masculine. Excepție face doar sufixul -ica, unde - a poate fi și moțional, cînd formează feminine de la masculine derivate cu -ică: Stan - Stănică Stănica. Pentru toate sufixele în discuție autorul aduce precizări importante privind originea, valoarea şi productivitatea lor în limba română.

În Transhumanțăși toponimie în Oltenia (p. 173176) se discută dinamica toponimiei minore desemnînd fenomenul transhumanței în contextul schimbărilor politice și social-economice survenite de-a lungul timpului. Toponime precum Drumu Oii / Drumu Oilor, Drumu Lînii, Drumu Ungurenilor, Drumul Munteanului sau Drumu Mocanilor, înregistrate în Oltenia în perioada păstoritului de transhumanță, își reduc frecvența începînd cu secolul al XXlea, cînd această practică începe să dispară treptat în favoarea păstoritului local. Prin urmare, aceste microtoponime sînt concurate și, ulterior, eliminate de toponime minore cu o mai mare relevanță pentru actualii localnici (Drumul Oii $\rightarrow$ Drumu Muierii, denumit astfel deoarece se află în imediata apropiere a Dealului Muierii).

În Antroponime huţule (p. 177-182), autorul identifică, prin aceeaşi metodă a geografiei antroponimice, vatra unor antroponime huțule plecînd de la arealul în care se află în uz baza apelativică reprezentată de un termen dialectal ${ }^{9}$. Astfel, pe baza frecvenței ridicate în nordul Moldovei, cercetătorul califică drept huțule antroponime precum Boroda (< ucr., rus. borodá „barbă”, lexem propriu graiului huțul), Cuhăr (< kuhar „bucătar”), predominant în județul Suceava, Strilaț/Strilețchi/Striliciuc (< strilac „vinnător”), $Z u b$ (< ucr., rus. $z u b$ „dinte”), cu derivatele $Z u b a s ̧$ și $Z u b a s ̧ c u$, frecvente în nordul țării etc.

Toate aceste studii, precedate de Argument, Bibliografie și Abrevieri și urmate de un scurt rezumat în limbile engleză și italiană, alcătuiesc un volum fundamentat pe cercetarea laborioasă atît a toponimiei românești, cu privire specială asupra Cîmpiei Băileștiului, cît și a antroponimiei noastre, în special a numelor de familie, analizate predilect din perspectiva geografiei antroponimice. Dincolo de micile neajunsuri care decurg din culegerea pe alocuri defectuoasă a textului la calculator, ne aflăm în fața unei lucrări de referință pentru publicul interesat de onomastică și dialectologie românească, cu atît mai mult cu cît autorul pune în discuție diversele teme abordate în contextul complementarităţii acestor două ramuri ale lingvisticii cu etnografia, semantica, morfologia și sociolingvistica.

\footnotetext{
${ }^{9}$ Analiza acestor apelative care au stat la baza poreclelor și, ulterior, a numelor de familie înregistrate în BDAR este fundamentată pe informații preluate din lucrarea lui Ioan Pătruț, Fonetica graiului huţul din Valea Sucevei (1957).
} 